$\begin{array}{ll}\text { Türkiye Tarımsal Araştırmalar Dergisi } & \text { Turk J Agric Res } \\ \text { dergipark.gov.tr/tutad } & \text { (2017, 4(3): 302-310 } \\ \text { IUETAD } & \text { ISSN: 2148-2306 } \\ \text { e-ISSN: 2528-858X } & \text { doi: 10.19159/tutad.310507 }\end{array}$

\title{
Tarımsal Biyoteknolojide Mobil Genetik Elementlerin Moleküler Markör Olarak Kullanılması
}

\author{
Arzu KOÇAK, Behcet İNAL*
}

Siirt Üniversitesi, Ziraat Fakültesi, Tarımsal Biyoteknoloji Bölümü, Siirt, TÜRKİYE

\begin{tabular}{ll}
\hline \multicolumn{1}{c}{ Geliş Tarihi/Received: 04.05 .2017} & Kabul Tarihi/Accepted: 23.08 .2017 \\
\hline ORCID ID (Yazar sirasina göre / by author order) & \\
\hline (Dorcid.org/0000-0001-7511-5687 (Dorcid.org/0000-0003-2215-2710 \\
*Sorumlu Yazar/Corresponding Author: behcetinal@siirt.edu.tr
\end{tabular}

Özet: Moleküler markör tekniklerinin temeli, melezleme veya polimeraz zincir reaksiyonuna (PZR) dayanır. Farklı stratejilerin bir kombinasyonu olarak yeni ve ileri teknikler geliştirilmiştir; örneğin cDNA'lar, spesifik dizilerin enzim kesimi veya kullanımı, ifade edilmiş dizi etiketleri (EST'ler), mikrosatellitler, retrotranspozonlar olarak sıralanabilir. Retrotranspozonlar bir tür (Sınıf I) transpoze olabilen (genomda farklı yerlere entegre olabilen) elementlerdir. Transpozon elementleri (TE) bitkilerde fiziksel olarak genomun önemli bir kısmını oluştururlar. Retrotranspozonlar aynı zamanda, amplifikasyon mekanizmaları ve dizilim karakteristikleri nedeniyle moleküler markör teknikleri geliştirmek için de oldukça ideal genetik elementlerdir. Bunlardan bazıları; Retrotranspozon-Arası Coğaltılmıs Polimorfizm, RetrotranspozonMikrosatellit Çoğaltılmış Polimorfizm, Primer Bağlanma Yeri Arası Çoğaltım, Dizilim-Spesifik Çoğaltım Polimorfizmi, Retrotranspozon Temelli İnsertion Polimorfizmi, SINE-Arası Çoğaltılan Polimorfizm, RAPD-Retrotranspozon Çoğaltılan Polimorfizm, Ters Dizilim Etiketli Tekrarlar, MITE-Arası Polimorfizm ve Transpoze Olabilen Gösterim bulunmaktadır. Bu metotlar farklı tarımsal ıslah amaçları için yaygın bir şekilde kullanılmaktadır. Bunlardan bazıları genetik çeşitliliğin, genetik bağlantının belirlenmesi, genom haritalaması, DNA parmak izi analizi, filogenetik, somaklonal varyasyon çalışmaları, transgenik araştırmaları, gelişim biyolojisi ve mutagenesis çalışmalarında kullanılmaktadır. Bu çalışmada, farklı retrotranspozon-temelli markör tiplerinin tarımsal biyoteknolojide genel kullanım alanlarından ve potansiyel uygulamalarından bahsedilecektir.

Anahtar Kelimeler: Transpozon, biyo markör, bitki, biyoteknoloji, 1slah

\section{The Use of Mobile Genetic Elements as Molecular Marker in Agricultural Biotechnology}

\begin{abstract}
The basis of molecular marker techniques are based on hybridization or Polymerase Chain Reaction (PCR). New and improved techniques have been developed as a combination of different strategies such as; cDNAs, enzyme digestion or the utilization of specific sequences; e.g. expressed sequence tags, microsatellites, and retrotransposons. Retrotransposons are a class (Class I) of transposable elements. Transposon elements physically form an important part of the genome in plants. Retrotransposons are also an ideal target for developing molecular marker techniques because of their amplification mechanism and sequence characteristics. Some of these are; Inter-Retrotransposon Amplified Polymorphism, Retrotransposon-Microsatellite Amplified Polymorphism, Inter Primer Binding Site Amplification, Sequence-Specific Amplification Polymorphism, Retrotransposon Based Insertion Polymorphism, Inter Sine Amplified Polymorphism, RAPDRetrotransposon Amplified Polymorphism, Inverse Sequence Tagged Repeats, Inter-MITE Polymorphism and Transposable display. These methods are used widely for different breeding purposes. Some of those are used in determination of genetic diversity, genetic linkage, genome mapping, DNA fingerprint analysis, phylogenetics, somaclonal variation studies, transgenic research, developmental biology, and mutagenesis studies. In this article, the common uses and potential applications of different retrotransposon-based marker types in agricultural biotechnology will be discussed.
\end{abstract}

Keywords: Transposon, biomarker, plant, biotechnology, breeding 


\section{Giriş}

Transpozon elementleri genom içinde konumlarını değiştirebilen tekrar dizileridir ve etki şekillerine göre iki ana gruba ayrılırlar. Sınıf I (veya retrotranspozonlar), ara RNA'lar yoluyla çoğalarak ve yeni bölgelere girerek bir kes-yapıştır tarzında hareket ederler. Sinif II (veya DNA transpozonları), genom içinde orijinal konumlarından çıkıp yeni bir bölgeye kes yapıştır tarzında girerek hareket ederler. Her bir TE sinıfi daha da alt sinıflara, dizilere ve süper ailelere ayrılır (Wicker ve ark., 2007). Transpozon aktivitesinin genomik çeşitliliği sağlamada ve türlerin evriminde önemli bir faktör olduğu ortaya konmuştur (Feschotte ve ark., 2002). Bu nedenle, akraba türler arasında; korunan kodlayan dizilerin aksine transpozon düzenlemeleri, akraba canlılar arasında bile değişkenlik göstermektedir.

Transpozon elementlerin bolluğu ve polimorfizmleri bazı moleküler markör sınıfları geliştirmek için kullanılmıştır ve bunların çoğu TE insersiyon bölgelerini kullanmaktadırlar (Kalendar ve ark., 2011). TE insersiyonları ve içinde girdikleri lokus dizileri arasındaki sınırlardan oluşan eşsiz birleşme noktaları oluştururlar (Bennetzen, 2000). Yakın zamanlarda, You ve ark. (2010) beş sınıf TE-birleşme noktasına dayalı markör sınıfının otomatize tasarımı için RJPrimer yazılımını geliştirmiştir. Bunlar arasında tekrar birleşme noktası-birleşme noktası markörleri (RJM'ler), insersiyon-yeri temelli polimorfizm (ISBP), retrotranspozon arası çoğaltılan polimorfizm ve retrotranspozon-temelli insersiyon polimorfizmi bulunmaktadır. $\mathrm{Bu}$ markörlerden ISBP ve RJM yüksek çıktılı genotipleme için kullanışlıdır; çünkü, fazla sayıda primer çifti üretirler (You ve ark., 2010). Ancak ISBP markörleri sadece TE dizilerine dayalı olarak geliştirilmelerine karşın, RJM'ler hem TE hem de gen dizilerini kapsayabilir ve genleri yakalayabilirler. $\mathrm{Bu}$ nedenle RJM'ler fonksiyonel genomik çalışmalarda ISBP'ye nazaran ekstra bir avantaja sahiptir. RJM tasarımı eşsiz TE birleşme noktası dizisini kaplayan bir primer ve herhangi tip bir diziden başka bir primer belirlemeyi ilgilendirir (Devos ve ark., 2005).

$\mathrm{Bu}$ derlemede, TE elementlerin birçok moleküler fonksiyonlarının yanı sıra, önemli bir markör grubu olduklarından bahsedilmiştir. Ayrıca TE'lerin bitki biyoteknolojisindeki kullanım alanları ve markör görevi üstlenerek gerçekleştirdikleri fonksiyonların ne denli önemli oldukları detaylı bir şekilde ele alınmıștır. Bu derleme ile beraber TE'lerin moleküler markör olarak tarımsal biyoteknolojideki kullanım yaygınlığının artacağı tahmin edilmektedir.

\section{Bitkilerde Moleküler Markör Yaklaşımları}

Mutasyonlar ve genetik rekombinasyon gibi kalitsal materyal değişiklikleri bir populasyon içindeki genetik çeşitliliğe katkıda bulunmaktadır. Son yıllarda DNA dizisinde herhangi bir değişiklik olmadan genlerin ekspresyonundaki değişikliklerin (epigenetik değişiklikler) de varyasyon üzerinde önemli faktör olduğu belirlenmiştir. Genetik varyasyonlar genlerde, bireyler arasinda ve bir populasyonda, meydana gelebilir. İnsan genom projesinin tamamlanmasının bir sonucu olarak (diğer genom projelerini müteakiben), teknükleotit polimorfizmleri (SNP'ler), insersiyondelesyon polimorfizmleri (INDEL), kopya sayıs1 varyasyonları $(\mathrm{CNV})$ ve gen retrokopya insersiyon polimorfizmleri (GRIP'ler) tanımlanmıştır (Wong ve ark., 2013). DNA'daki bu tip bireysel varyasyonlar polimorfizm olarak tanımlanmaktadır. Biyoenformatik metotlar ve genom-temelli çalışmaların ilerlemesi ile beraber keşfedilen varyasyonların çok faktörlü kalıtımla ilişkili oldukları bulunmuştur. Ayrıca genetik varyasyon analizi, genom-çapında kromozomal yap1 değişikleri konu alan analizlerde de yeni yaklaşımların oluşmasını sağlamıştır. Söz konusu bu araştırmalar, mevcut genomik varyasyon mekanizmalarının evriminin temelini oluşturmakta ve bu amaçla yapılan analiz ve çabalara katkıda bulunmaktadır.

DNA markörleri; genetik değişkenlik ve çeşitlilik analizinde, bağlantı haritaları oluşturulmasında ve bazı bağlantılı genleri taşıyan bireylerin veya hatların belirlenmesinde temel bir rol oynarlar. Moleküler markör sistemleri Drosophila pseudoobscura doğal populasyonlarında gen heterozigotluğu konusundaki sonuçların yayınlanmasından sonra son 40 yıldır kullanılmaktadırlar (Hubby ve Lewontin, 1966). Moleküler markör belli bir özellikle ilişkili olan ve nesiller boyu aktarılabilen bir nükleotit dizisidir. Moleküler markör teknikleri; ya melezlemeye (RFLP gibi DNA-DNA melezlemeleri), ya da PZR tekniğine dayanmakta ve örnekler arasındaki DNA polimorfizmlerini kullanmaktadırlar. Çeşitli PZR temelli markörler farklı amaçlar için yaygın şekilde kullanılmaktadır ve bu markörlerin teknik özellikleri yaygın şekilde araştırılmıştır.

\subsection{Transpozon temelli moleküler markörler}

Transpozonlar, özellikle de uzun bitiş tekrarları "long terminal repeat" (LTR) retrotranspozonlar, bitki genomlarının yüksek bir yüzdesini oluştururlar. "Kes-yapıştır” mekanizmasından 
dolayı retrotranspozonlar; RNA ara aşaması ile bir genomda, farkl1 yerlere girebilmekte ve mutasyonlara neden olabilmektedirler. Transpozonların genomdaki sayılarının fazlalığı genellikle genom büyüklüğü ile ilişkilidir (Schulman ve Kalendar, 2005). LTR retrotranspozonların bitki genomlarındaki; yaygınlığı, bolluğu, dağılması ve dinamizmi bu genetik elementleri önemli moleküler markör kaynakları haline getirmiştir (Kalendar ve Schulmann, 2006; Poczai ve ark., 2013). Retrotranspozon dizileri tek başına veya genomdaki çeşitli diziler ile birlikte primer bağlanma bölgeleri sağlarlar. Bir retrotranspozonun LTR'leri farklı organizmalar arasında korunan dizilere sahiptir. Bu nedenle, spesifik bir organizma için geliştirilen bir primer çifti bir diğer organizma için kullanılabilir. Ancak bir organizmanın farklı retrotranspozonları farklı LTR dizilerine sahiptir; bu nedenle, spesifik bir retrotranspozon için geliştirilmiş olan spesifik bir primer çifti bir diğerinin LTR'sine bağlanamaz. Aşağıda transpozon temelli markör tekniklerinin bazılarının benimsediği yaklaşımlar açıklanmış ve birbirleri ile karşılaştırılarak potansiyel avantaj ve dezavantajları tartışılmıştır.

\subsubsection{Ters dizilim etiketli tekrar (ISTR)}

ISTR metodu seçici PZR amplifikasyonuna dayanan çok lokuslu bir markör sistemidir. $\mathrm{Bu}$ metotta, primerler genomda dağılmış olan yüksek kopyalı bir DNA dizisinden diş yöne doğru geliştirilmiştir. ISTR primerlerinin amplifikasyon ürünleri poliakrilamid jellerde çözülür ve çok lokuslu polimorfik bantlar skorlanır. İlk ISTR primerleri Hindistan cevizi copia-benzeri retrotranspozonundan geliştirilmiştir. Çeşitli bitki türlerinin Hindistan cevizi dizilerinden geliştirilen aynı primerler kullanılarak yapılan ISTR analizleri, bu primerlerin evrensel olarak kullanılabilir olduğunu göstermiştir (Aga ve Bryngelsson, 2006).

\subsubsection{Dizilim-spesifik çoğaltılmış polimorfizm (S-SAP)}

S-SAP dominant ve mültipleks bir markör sistemidir. İlk retrotranspozon-temelli moleküler markördür ve Çoğaltılmış Parça Uzunluğu Polimorfizm marköründen (AFLP) modifiye edilmiştir (Waugh ve ark., 1997). AFLP tekniği seçici PZR amplifikasyonuna bir anlamda genomik DNA toplamının kesiminden gelen kesim parçalarına dayanmaktadır (Vos ve ark., 1993). SSAP'de, genomik DNA ilk olarak iki restriksiyon endonükleaz ile kesilir ve daha sonra kesim enzimlerine spesifik adaptörler yapıştırılır. Template (üzerinde çoğaltım yapılacak kalıp
DNA) adaptörlerde bulunan dizilerden geliştirilen primerler ile ön amplifikasyona tabi tutulur ve sonra da bire bir LTR'nin korunan bölgesinden geliştirilen, diğeri de bir seçici adaptör primeri olan iki primer ile seçici şekilde çoğaltılır. Seçici adaptör primerleri 3' ucunda ilave nükleotitlere (1-3) sahiptir. PZR ürünleri formamid içeren jel yükleme çözeltisi ile denatüre edilir ve daha sonra poliakrilamid jel elektroforezi (PAGE) ile çözülürler. S-SAP genelde; AFLP'den daha az sayıda bant verse de, polimorfizm yüzdesi $\mathrm{S}$ SAP'da daha yüksektir (Waugh ve ark., 1997). SSAP transpozon gösterim (TD) metoduna çok benzerdir (Van Den Broeck ve ark., 1998).

\subsubsection{Retrotranspozon-temelli insersiyonel polimorfizm (RBIP)}

RBIP mültipleks, S-SAP mültipleksine bir alternatif olarak düşünülmüştür. Bireysel transpozon insersiyonları RBIP ile, konukçuyaspesifik PZR primerleri ve bir transpozona spesifik primer kullanılarak belirlenir. Transpozonun insert olduğu hedeften (konukçu) iki PZR primeri geliştirilir ve ilave bir transpozona spesifik primer geliştirilir. DNA örnekleri konukçu primerleri veya transpozon primeri ile kombine edilen bir konukçu primer ile çoğaltılır. Bir transpozonun insersiyon lokusunun büyüklüğünü değiştirir. Polimorfizm agaroz jel elektroforezi ile veya dot-blot analizi ile belirlenebilir. Böylece, belli bir lokusun allelik durumları belirlenir. RBIP lokus spesifiktir ve basit dizi tekrarları (SSR)'lar gibi eş-baskındır. Hem RBIP ve hem de SSR markörlerinin en önemli kısıtlaması her bir markör etrafındaki kromozom bölgesinin dizilim bilgisine ihtiyaç duymasıdır. SSR markörleri genomik kütüphaneleri basit dizilim tekrarları için taramayla geliştirilir. RBIP markörleri ise S-SAP yaklaşımı ile belirlenebilir (Flavell ve ark., 1998). RBIP'in önemli bir avantajı TaqMan veya DNA chip teknolojisi gibi jel kullanmayan işlemlerle çalışılan örnek miktarını artırmak için kolayca kullanılabilmesidir.

\subsubsection{Retrotranspozon-arası çoğaltılmış polimorfizm (IRAP)}

IRAP çok lokuslu dominant bir tekniktir. Bu teknik ilk olarak BARE-1 (arpa Retroelement 1) dizisi kullanılarak geliştirilmiştir (Kalendar ve ark., 1999). BARE-1 ailesi yaklaşık $1.5 \times 10^{4}$ tam uzunlukta kopyaya ve $1.7 \times 10^{5}$ solo LTR'ye sahiptir (Vicient ve ark., 1999). IRAP korunan LTR dizilerinden dişarıya doğru bir yönde geliştirilen PZR primerleri ile kullanır. İki LTR arasındaki veya yalnız LTR'ler arasındaki iç bölgeler çoğaltılır. Amplifikasyon ürünlerinin bant büyüklükleri BARE-1 elementinin yerel 
kümelenmesini, fakat büyük ölçekteki dağılmasını desteklemektedir (Kalendar ve ark., 1999). Retrotranspozonlar tahıl genomlarında diğer elementlerin içine yuvalanma eğilimindedirler (Vicient ve ark., 2001). Primerlerin hedefleri (LTR'nin 5' veya 3' ucu) farklı amplikonlar üretirler ve bant oluşum biçimlerini değiştirirler. Bir bantın görünüşü bir diğer unsurdan çoğaltılabilir bir mesafede olan yeni bir insersiyonu yansitır. Bu teknikte DNA örnekleri tek veya iki primerle çoğaltılır. Bu tekniğin önemli avantajları restriksiyon enzimi ile kesim veya DNA yapıștırma aşamalarının bulunmamasıdır ve PZR ürünleri agaroz jel yardımı ile ayrılır. Yüksek bant sayısından dolayı DNA miktarları optimize edilmelidir. Yüksek kalıp DNA konsantrasyonları aşırı amplifikasyona yol açabilir (Kalendar ve ark., 1999; Kalendar ve Schulman, 2006). Yüksek kalitedeki agarozlarda yavaş elektroforez bantların çözünürlüğünü artırır. DNA örneklerindeki kirliliklere ve PZR aşamalarına müdahale edebilir.

\subsubsection{Retrotranspozon-mikrosatellit çoğaltılmış polimorfizmi (REMAP)}

REMAP da bir dominant ve mültipleks markör sistemi olup; IRAP'a benzemektedir, fakat REMAP bir LTR primeri ve yakınındaki bir mikrosatellite spesifik bir primer kullanmaktadır. $\mathrm{Bu}$ nedenle sadece iki LTR arasındaki bölgeler değil, fakat aynı zamanda bir LTR ve bir mikrosatellit arasındaki bölgeler de çoğaltılır (Kalendar ve ark., 1999). Basit dizilim tekrarları olarak da bilinen mikrosatellitler bitki ve hayvanlarda bulunan bir tekrarlanan dizi tipidir. Bu motifler birkaç kez tekrarlanan tek bir baz çifti veya az sayıda baz (genellikle 1'den 6'ya kadar değişir) içerebilir (Saha ve ark., 2003). SSR'lar bol sayıdadır, yüksek düzeyde polimorfiktir ve genom boyunca dağılmışlardır (Li ve ark., 2002). SSR'lar aynı zamanda bağımsız bir moleküler markör tekniği sağlamaktadırlar (Zietkiewicz ve ark., 1989). Dahası, SSR'lar arpada retrotranspozonlarla ilişkilidirler (Ramsay ve ark., 1999). REMAP metodundaki mikrosatellit primerleri, mikrosatelliti iki tarafından çevreleyen bölgelere yapışan orijinal SSR primerlerinden farklıdır. Diğer bir ifadeyle, bir LTR primeri SSR'ın kendisini içeren bir primer ile kombine olur. PZR şartları ve PZR ürünlerinin analizi IRAP şartlarına benzerdir (Kalendar ve ark., 1999; Kalendar ve Schulman, 2006). Ancak, bazı bantlar sadece SSR primerlerinden kaynaklanabilir (Leigh ve ark., 2003).

\subsubsection{MITE-arası polimorfizm (IMP)}

Her ne kadar minyatür ters-tekrar transpozable elementler (MITE'ler) terminal ters tekrarlara
(TIR'lar) sahipse de, onlar diğer bitki TE'den küçük olmalarıyla ( $<500$ bp) ve TAA veya TA tercihli bir hedef-yerine sahip olmalarıyla farklılık gösterirler. Dahası MITE'lerin genlerin yakınında veya içinde ki insersiyonu tercih ettiği görünmektedir ve birçok bitki genomunda ortayüksek sayıda bulunmaktadırlar. $\mathrm{Bu}$ özellikler MITE'lerden markörlerin geliştirilmesine yol açmıştır. IMP iki komşu MITE arasında amplifikasyonla ilgilidirler. Birkaç TIR dizisine uygun olan dejenere primerler geliştirilir. Amplifikasyon ürünleri poliakrilamid jellerde çözülürler (Chang ve ark., 2001).

\subsubsection{Terminal tekrar transpozon minyatür gösterimi (TRIM)}

TRIM elementleri (bir grup LTR retrotranspozonu) 100-300 bp uzunlukta bir iç bölgeyi kuşatan 100-150 bp uzunlukta terminal doğrudan tekrar (TDR) dizilerine sahiptir. İç bölge primer bağlanma bölgelerini ve birçoklu pürin iz motiflerini içerir, fakat hareketlilik için gerekli olan kodlayan bölgelerden yoksundur. Otonom olmayan özelliklerine rağmen, bitki genomlarının yeniden yapılandırılması ile ilgili oldukları belirtilmiştir (Witte ve ark., 2001). TRIM gösterimi AFLP tekniğinin bir modifikasyonuna dayanır (Vos ve ark., 1993). DNA örnekleri restriksiyon enzimi BfaI ile kesilir ve BfaI adaptörleri yapıştırılır. Yapıştırmadan sonra örnekler ilk olarak adaptörlerden birine tamamlayıc1 olan bir primer ile ve TRIM elementinin terminal tekrar dizilerinde korunan bir diziden geliştirilen bir primer ile çoğaltılır. Bir önseçici amplifikasyon ürünü, TRIM primeri ve (3' ucunda seçici bir nükleotit bulunan) bir $\mathrm{BfaI}+1$ primeri kullanılarak seçici amplifikasyon için kullanılır. Seçici amplifikasyon için touch-down PZR gerçekleştirilir. Amplifikasyon ürünleri poliakrilamit jellerde çözülür. TRIM gösterimi genomik DNA kullanılarak Brassicae türlerinde 100-700 bp uzunluğunda değișen 50-70 bant üretmiştir (Kwon ve ark., 2007).

\subsubsection{Primer arası bağlanma yeri (iPBS)}

LTR-retrotranspozonları 5' LTR yakınında primer bağlanma bölgelerine (PBS) sahiptir. Hücresel tRNA'nın 3' ucu PBS'ye bağlanır ve retrotranspozonun mRNA'sının sentezini başlatır (Kumar ve Bennetzen, 1999). iPBS metodunda iki LTR retrotranspozon arasındaki amplifikasyon olacak kadar yakın bölgeler zıt yönde çoğaltılır. PBS'nin korunan bölgelerinden primerler geliştirilir. iPBS 100-5000 bp uzunluğunda 15-50 bant üretmektedir. PBS dizilerinin incelenen genomlardaki yüksek kopya sayıları nedeniyle, iPBS çok sayıda net bant üretmektedir ve bunları 
etidyum bromid ile boyanan standart agaroz jellerde skorlamak kolaydır. iPBS metosu dominant markör olarak davranan polimorfik parmak izleri vermektedir (Kalendar ve ark., 2010).

\subsubsection{SINE-arası çoğaltılmış polimorfizm (ISAP)}

ISAP komşu SINE kopyaları arasında PZR ile genomik DNA çoğaltımına ve ortaya çıkan amplikonların sonrasında elektroforez ile ayrılmasına dayanır. İleri primer elementin 3' ucuna doğrudur, geri primer ise 5 , ucuna bakmaktadır. PZR ürünleri agaroz jel elektroforezi ile ayrilmaktadır (Seibt ve ark., 2012). Alu tekrar dizileri insanlarda parmak izi analizi için kullanılmaktadır (McKie ve ark., 1997).

\subsubsection{RAPD-retrotranspozon çoğaltılmış polimorpfizm (R-RAP)}

R-RAP bazı sınırlamaları olan rasgele çoğaltılmış polimorfik DNA (RAPD) ve IRAP tekniklerinin bir kombinasyonu olarak tasarlanmıştır. RAPD'de düşük tekrarlanabilirlik bir problem iken, IRAP'ta primer bağlanma bölgeleri amplikon ürününü üretemeyecek kadar uzak olabilir. DNA örnekleri 10 bazlık rastgele bir primer ile bir LTR primeri kullanılarak çoğaltılır. RAPD ve IRAP primerlerinin erime sicaklıkları büyük ölçüde farklılık gösterir, bu nedenle optimal yapışma sıcaklıklarının gradient PZR ile belirlenmesi gereklidir. Çoğaltım ürünleri agaroz jellerde çözülür. R-RAP lokuslarının sayısı 10 ile 17 arasında değişir ve yüksek çözünürlüğe ve tekrarlanabilirliğe sahiptir (Aalami ve ark., 2012).

\subsubsection{Gen retrokopya insersiyon polimorphizmi (GRIP)}

Bir veya daha fazla bireyde bir retrotranspoze olmuş insersiyon olarak mevcut olan, fakat referans genomda bulunmayan işlenmiş bir gen transkripti GRIP olarak adlandırılır (Ewing ve ark., 2013). İnsanlarda, pseudogenler asıl olarak L-1 ORF2 proteini ile gerçekleştirilir (Mathias ve ark., 1991; Feng ve ark., 1996; Esnault ve ark., 2000). İşlenmiş mRNA'ların genomda dağılmış insersiyonu olan insanlar, fareler ve şempanzelerde devam eden bir mutasyon mekanizmasıdır ve tümörlerde bulunabilirler (Ewing ve ark., 2013).

\section{Yüksek Çıktılı Teknolojiler İle Mobil Genetik Markörinin Tespit Edilmesi}

pMEI (mobil element insersiyonlar1) profilleme tüm genom seviyesinde iki gruba ayrilabilir: hedefli metotlar ve sekanslama sonrası biyoenformatik metotlar. Sekanslama veya genotiplemeden önce, MEI ile ilişskili DNA parçaları hedeflenen metotlarda deneysel olarak zenginleştirilir. Ayrıca, pMEI'ler sekanslama sonras1 biyoenformatik metotlar halinde tüm genom sekanslama verisini kullanarak tanımlanır (Xing ve ark., 2013).

Transpozon gösterim (TD) MEI seleksiyon tekniklerinden biridir. $\mathrm{Bu}$ jel temelli metot pMEI'leri Petunya türlerinde görüntülemek için Van Den Broeck ve ark. (1998) tarafindan geliştirilmiştir. TD insan genomunda Alu elementlerde de (Roy ve ark., 1999; Mamedov ve ark., 2005), L1'lerde (Sheen ve ark., 2000; Ovchinnikov ve ark., 2001; Badge ve ark., 2003) ve insan endojen retrovirüslerde de (HERVs) (Buzdin ve ark., 2003) insan genomunda çalışılmıştır. Son zamanlarda bazı teknikler TD metodunu yüksek çıktılı sekanslamaya entegre etmiştir (Iskow ve ark., 2010; Witherspoon ve ark., 2010; Ewing ve ark., 2013). Metodun temel prensibi çoklu aşamalar içerir. Başlangıçta MEI lokusundaki genomik DNA mekanik parçalama veya enzimle kesme ile MEI birleşme noktasını ve etrafindaki spesifik genom dizisini kapsayan çok sayıda parçaya ayrılır. Daha sonra adaptör oligonükleotitler parçacıklara yapıştırılır ve hedeflenen yarı-spesifik PZR reaksiyonu yardımı ile ilgilenilen mobil element ailesine bağlanan bir primer ve bir adaptör primer ile gerçekleştirilir. Burada, hedefleyen primer MEI taşıyan parçaların özel olarak yakalanmasını ve zenginleştirilmesini sağlamak için biotinlenmiştir. $\mathrm{Bu}$, mobil element taramada (ME-scan) kullanilan metottur (Witherspoon ve ark., 2010). Daha sonra, zenginleştirilmiş kütüphanedeki insersiyonlara bitişik olan veya onların bağlantı noktalarını kapsayan eşsiz genomik dizilerden okumalar üretmek için yüksek çıktılı sekanslama gerçekleştirilir; her iki okuma tipi de resim çıktısı prensipine dayanmaktadır (Xing ve ark., 2013).

Büyük ölçekli pMEI belirleme tüm genom verisini kullanarak bilgisayarla yapılabilir. Tüm genom verisinde yapısal varyasyonları (SV'ler) tanımlamak için geliștirilmiş olan birçok algoritma bulunmaktadır. Bu algoritmalar MEI özellikleri hakkında hiçbir şey bilmeden pMEI'leri belirleyebilir. Bunlardan biri "çıpalı okumaeşleştirmesi haritalaması" olarak tanımlanır ve eşleştirilmiş-uç okumalarını kullanarak MEI'leri belirler. İlk olarak, eşleştirilmiş uç okumaları referans genoma haritalanır. Bir okumanın eşsiz bir genom konumuna haritalandığı okuma çiftleri ve bir MEI konsensüs dizisine haritalanan diziler bir MEI varlığını ortaya koymaktadır (Xing ve ark., 2013). Bu algoritmanın uygulanması RetroSeq (Wong ve ark., 2010) ve polimorfik Alu insersiyonlarını tanımayı (PAIR) içerir 
(Sveinbjörnsson ve Halldórsson, 2012). "Bölünmüş-okuma haritalaması" adı verilen bir diğer algoritma MEI-genom bağlantı noktalarını kapsayan okumaları kullanarak tam MEI konumu belirlemek için tasarlanmıştır. Bu tip okuma MEI çıkarımında en yüksek güvenilirliği sağlamaktadır. Eğer bir okumanın bir parçası genomun eşsiz bir kısmına haritalanabilirse ve okumanın geri kalan kısmı MEI dizisine haritalanırsa, ilgili dizi pozisyonu belirlenebilir (Xing ve ark., 2013).

\section{Biyoenformatik ve Mobil Genetik Element Analizleri}

Son zamanlarda, dizilenmiş olan genomlardaki transpozon element (TE)'lerin ortaya konması için bazı biyoenformatik yazılımlar geliştirilmişse de, genom-boyu yaklaşımlar kullanarak aktif TE'lerin belirlenmesine adanmış çok az hesaplama aracı bulunmaktadir. Search TESV, Yeni Nesil Dizileme (NGS) teknolojileri kullanarak TE-İlişkili yapısal varyantların (TEASV'ler) belirlenmesi için araştırmacıların geliştirdiği bir araçtır. Yakın zamanlarda TE tekrar bağlantı noktalarını (RJ'ler) de bildirilmiştir ve arpa sekanslama verisini kullanarak fazla sayıda RJM tasarlanmıştır (Mazaheri ve ark., 2014).

\section{Geçmişten Günümüze Mobilom Çalışmaları}

Çok sayıda bitki genomunun sekanslanması ile tüm genom duplikasyonu ve TE'lerin angiosperm genomlarının organizasyonu üzerindeki etkileri daha iyi anlaşılmıştır (Kejnovsky ve ark., 2009). Mobil genetik elementlerin (MGE'ler) belirlenmesi asıl olarak konsensüs-benzeri araştırmalara dayanmaktadır. $\mathrm{Bu}$ araştırmalarda, araştırılan genom zaten tanımlanmış olan bir mobil element dizisi için taranmaktadır. Mobilomik alanındaki araştırmaların amacı tüm MGE'lerin keşfedilmesi ve gelecek kuşak sekanslama kullanmayla onların genomdaki dinamik davranışının anlaşılmasıdır. Yakın akraba organizmaların karşılaştırılabilir genomikleri hakkındaki çalışmalar mobilomikten elde edilen bilgileri destekleyebilir. Bu tip verinin miktarı güçlü hesaplama çabalarına ihtiyaç duymaktadır (Menconi ve ark., 2013). Retrotranspozisyon veya retroCNV'ler ile sağlanan gen kopya sayısı varyantlarını doğru şekilde belirlemek için birçok metot bulunmaktadır (Schrider ve ark., 2013).

\section{Transpozonların ve Transpozon Temelli Markörlerin Diğer Kullanım Alanları}

Vernalizasyon genlerindeki TE ile sağlanan birkaç mutasyon buğdayın çok çeşitli ortamlara adapte olmasını sağlayan gelişme tiplerindeki değişikliklerden sorumlu olduğu bulunmuştur (Chu ve ark., 2011). TE baskılama mekanizmaları kurağa toleransla ilişkilidir (Lopes ve ark., 2013). Transpozon temelli markör teknikleri filogenetik, moleküler ekoloji, biyoçeşitlilik, bağlantı haritalaması ve fonksiyonel genomik çalışmaları gibi çok çeşitli çalışma alanlarına sahiptir (Kwon ve ark., 2005; Kang ve Kang, 2008; Soorni ve ark., 2013). Çeşitli retrotranspozon ailelerinin farkli insersiyon aktivitelerinden dolayı, üretilen markör sayısı büyük ölçüde farklılık göstermektedir ve bu durum filogenetik analiz için ihtiyaç duyulan çözünürlüğe bağlı olarak uygun retrotranspozon ailesinin seçimine imkân vermektedir (Leigh ve ark., 2003). IRAP muz hatlarının sinıflanmasinda (Nair ve ark., 2005; Teo ve ark., 2005), genotoksisitenin belirlenmesinde (Hamat-Mecbur ve ark., 2014), IRAP ve REMAP zencefil, çeltik ve buğdayda genetik çeşitlilik ve benzerlik analizinde (Branco ve ark., 2007, Carvalho ve ark., 2012, Nasri ve ark., 2013; Pandotra ve ark., 2013) ve arpada haritalamada (Manninen ve ark., 2000) kullanılmıştır.

\section{Sonuçlar}

$\mathrm{Bu}$ çalışmada retrotranspozon markörlerinin sınıflandırılması ve özelliklerinden bahsedilmiştir. Transpozonların yapısını, tiplerini ve yaşam döngülerini bilsek de; onların orijini, fonksiyonları, evrim sürecindeki rolü ve gen ekspresyonu üzerine etkileri konusunda daha fazla bilgiye ihtiyaç duyulmaktadır. Hedeflenen, retrotranspozon markörleri listelemek, metodolojilerini ve prensiplerini özetlemek ve bulguları gözden geçirmekti. $\mathrm{Bu}$ bağlamda retrotranspozon markörleri konusundaki daha önce yapılmış güncel sayılabilecek çok sayıda çalışmalardan bahsedilmiştir. Bu tip çalışmaların gen yap1s1, gen ekspresyonunun düzenlenmesi, transgenik araştırmaları, evrim ve hücre farklılaşması konularının daha da anlaşılmasına 1şık tutacağı söylenebilir.

TE'ler bitki genomunun önemli bileșenlerinden biridir ve fonksiyonel genom çeşitliliği ve 
fenotipik varyasyonlarda kritik bir rol oynadıkları bildirilmiştir. $\mathrm{Bu}$ nedenle, genomda TE'lerin organizasyonunu analiz etme araştırmacıların TE'ler ve yakındaki gen ekspresyonu arasındaki etkileşimleri ortaya çıkarmasına imkân verecektir. $\mathrm{Bu}$ konu kültür bitkilerinin fenotipik çeşitliliğini şekillendirmede TE'lerin rolünü anlamamızı geliştirecektir. Gelecek kuşak sekanslama ve yüksek çıktılı sekans analiz platformlarının geliştirilmesi tüm genom sekanslamayı ve önemli kültür bitkilerinin analizini mümkün kılmıştır. Genom sekans bilgisinin varlığı ile birlikte, genomda TE'lerin organizasyonunu araştırmak mümkündür. Dahası, retrotranspozonlar gibi birkaç tip TE'nin polimorfik potansiyeli, yüksek çıktılı genotipleme uygulamaları için kullanışlı olan TE temelli moleküler markörlerin gelişimini teşvik etmiştir (Poczai ve ark., 2013). Genom evriminin temel sebebi TE'lerdir ve TE'ler seleksiyonun gerçekleştirilebileceği genetik çeşitlilik üretmişlerdir. Dahası TE transpozisyonu nükleotit temelli mutasyon oranı için de önemli bir faktördür ve böylece TE'ler evrimsel değişiklikler için potansiyel bir etmen olarak hizmet etmektedirler. TE, kültürü yapılan bitkilerin kültüre alınması ve çeşitlenmesi ile ilişkili olan fenotipik değişiklikler meydana getirir. TE aynı zamanda, intron veya ekzon bölgesi içinde insersiyon veya delesyon yapmayla genleri bozmaya yol açar ve bu genin farklı ekspresyonu ve düzenlenmesinde önemli bir faktör olabilir.

\section{Kaynaklar}

Aalami, A., Safiyar, S., Mandoulakani, B.A., 2012. RRAP: A retrotransposon-based DNA fingerprinting technique in plants. Plant Omics, 5(4): 359-364.

Aga, E., Bryngelsson, T., 2006. Inverse sequence-tagged repeat (ISTR) analysis of genetic variability in forest coffee (Coffea arabica L.) from Ethiopia. Genetic Resources and Crop Evolution, 53(4): 721-728.

Badge, R.M., Alisch, R.S., Moran, J.V., 2003. ATLAS: A system to selectively identify human-specific L1 insertions. The American Journal of Human Genetics, 72(4): 823-838.

Bennetzen, J.L., 2000. Transposable element contributions to plant gene and genome evolution. Plant Molecular Biology, 42(1): 251-269.

Branco, C.J., Vieira, E.A., Malone, G., Kopp, M.M., Malone, E., Bernardes, A., Mistura, C.C., Carvalho, F.I.F., Oliveira, C.A., 2007. IRAP and REMAP assessments of genetic similarity in rice. Journal of Applied Genetics, 48(2): 107-113.

Buzdin, A., Ustyugova, S., Khodosevich, K., Mamedov, I., Lebedev, Y., Hunsmann, G., Sverdlov, E., 2003. Human-specific subfamilies of HERV-K (HML-2) long terminal repeats: three master genes were active simultaneously during branching of hominoid lineages. Genomics, 81(2): 149-156.
Carvalho, A., Henrique Guedes-Pinto, H., Lima-Brito, J.E., 2012. Genetic diversity in old Portuguese durum wheat cultivars assessed by retrotransposonbased markers. Plant Molecular Biology Reporter, 30(3): 578-589.

Chang, R.Y., O'Donoughue, L.S., Bureau, T.E., 2001. Inter-MITE polymorphisms (IMP): a high throughput transposon-based genome mapping and fingerprinting approach. Theoretical and Applied Genetics, 102(5): 773-781.

Chu, C.G., Tan, C.T., Yu, G.T., Zhong, S., Xu, S.S., Yan, L., 2011. A novel retrotransposon inserted in the dominant Vrn-B1 allele confers spring growth habit in tetraploid wheat (Triticum turgidum L.). G3: Genes, Genomes, Genetics, 1(7): 637-645.

Devos, K.M., Ma, J., Pontaroli, A.C., Pratt, L.H., Bennetzen, J.L., 2005. Analysis and mapping of randomly chosen bacterial artificial chromosome clones from hexaploid bread wheat. Proceedings of the National Academy of Sciences of the United States of America, 102(52): 19243-19248.

Esnault, C., Maestre, J., Heidmann, T., 2000. Human LINE retrotransposons generate processed pseudogenes. Nature Genetics, 24(4): 363-367

Ewing, A.D., Ballinger, T.J., Earl, D., Broad Institute Genome Sequencing and Analysis Program and Platform, Harris, C.C., Ding, L., Wilson, R.K., Haussler, D., 2013. Retrotransposition of gene transcripts leads to structural variation in mammalian genomes. Genome Biology, 14(3): R22.

Feng, Q., Moran, J.V., Kazazian, H.H., Boeke, J.D., 1996. Human L1 retrotransposon encodes a conserved endonuclease required for retrotransposition. Cell, 87(5): 905-916.

Feschotte, C., Jiang, N., Wessler, S.R., 2002. Plant transposable elements: Where genetics meets genomics. Nature Reviews Genetics, 3(5): 329-341.

Flavell, A.J., Knox, M.R., Pearce, S.R., Ellis, T.H.N., 1998. Retrotransposon-based insertion polymorphisms (RBIP) for high throughput marker analysis. The Plant Journal, 16(5): 643-650.

Hamat-Mecbur, H., Yımaz, S., Temel, A., Şahin, K., Gözükırmızı, N., 2014. Effects of epirubicin on barley seedlings. Toxicology and Industrial Health, 30(1): 52-59.

Hubby, J.L., Lewontin, R.C., 1966. A molecular approach to the study of genic heterozygosity in natural populations. I. the number of alleles at different loci in Drosophila pseudoobscura. Genetics, 54(2): 577-594.

Iskow, R.C., McCabe, M.T., Mills, R.E., Torene, S., Pittard, W.S., Neuwald, A.F., Van Meir, E.G., Vertino, P.M., Devine, S.E., 2010. Natural mutagenesis of human genomes by endogenous retrotransposons. Cell, 141(7): 1253-1261.

Kalendar, R., Antonius, K., Smykal, P., Schulman, A.H., 2010. iPBS: A universal method for DNA fingerprinting and retrotransposon isolation. Theoretical and Applied Genetics, 121(8): 14191430. 
Kalendar, R., Flavell, A.J., Ellis, T.H.N., Sjakste, T., Moisy, C., Schulman, A.H., 2011. Analysis of plant diversity with retrotransposon-based molecular markers. Heredity, 106(4): 520-530.

Kalendar, R., Grob, T., Regina, M., Suoniemi, A., Schulman, A.H., 1999. IRAP and REMAP: Two new retrotransposon-based DNA fingerprinting techniques. Theoretical and Applied Genetics, 98(5): 704-711.

Kalendar, R., Schulman, A.H., 2006. IRAP and REMAP for retrotransposon-based genotyping and fingerprinting. Nature Protocols, 1(5): 2478-2484.

Kang, H.W., Kang, K.K., 2008. Genomic characterization of Oryza species-specific CACTAlike transposon element and its application for genomic fingerprinting of rice varieties. Molecular Breeding, 21(3): 283-292.

Kejnovsky, E., Hobza, R., Cermak, T., Kubat, Z., Vyskot, B., 2009. The role of repetitive DNA in structure and evolution of sex chromosomes in plants. Heredity, 102(6): 533-541.

Kumar, A., Bennetzen, J.L., 1999. Plant retrotransposons. Annual Reviews in Genetics, 33(1): 479-532.

Kwon, S.J., Kim, D.H., Lim, M.H., Long, Y., Meng, J.L., Lim, K.B., Kim, J.A., Kim, J.S., Jin, M., Kim, H.I., Ahn, S.N., Wessler, S.R., Yang, T.J., Park, B.S., 2007. Terminal repeat retrotransposon in miniature (TRIM) as DNA markers in Brassica relatives. Molecular Genetics and Genomics, 278(4): 361-370.

Kwon, S.J., Park, K.C., Kim, J.H., Lee, J.K., Kim, N.S., 2005. Rim 2/Hipa CACTA transposon display; A new genetic marker technique in Oryza species. BMC Genetics, 15(6): 1-13.

Leigh, F., Kalendar, R., Lea, V., Lee, D., Donini, P., Schulman, A.H., 2003. Comparison of the utility of barley retrotransposon families for genetic analysis by molecular marker techniques. Molecular Genetics Genomics, 269(4): 464-474.

Li, Y.C., Korol, A.B., Fahima, T., 2002. Microsatellites: genomic distribution, putative functions and mutational mechanisms: a review. Molecular Ecology, 11(12): 2453-2465.

Lopes, F.R., Jjingo, D., Da Silva, C.R., Andrade, A.C., Marraccini, P., Teixeira, J.B., Carazzolle, M.F., Pereira, G.A., Pereira, L.F., Vanzela, A.L., Wang, L., Jordan, I.K., Carareto, C.M., 2013. Transcriptional activity, chromosomal distribution and expression effects of transposable elements in Coffea genomes. Plos One, 8(11): e78931.

Mamedov, I.Z., Arzumanyan, E.S., Amosova, A.L., Lebedev, Y.B., Sverdlov, E.D., 2005. Wholegenome experimental identification of insertion/deletion polymorphisms of interspersed repeats by a new general approach. Nucleic Acids Research, 33(2): e16.

Manninen, O., Kalendar, R., Robinson, J., Schulman, A.H., 2000. Application of BARE-1 retrotransposon markers to the mapping of a major resistance gene for net blotch in barley. Molecular and General Genetics, 264(3): 325-334.

Mathias, S.L., Scott, A.F., Kazazian, H.H., Boeke, J.D., Gabriel, A., 1991. Reverse transcriptase encoded by a human transposable element. Science, 254(5039): 1808-1810.

Mazaheri, M., Kianian, P.M.A., Mergoum, M., Valentini, G.L., Seetan, R., Pirseyedi, S.M., Kumar, A., Gu, Y.Q., Stein, N., Kubaláková, M., Doležel, J., Denton, A.M., Kianian, S.F., 2014. Transposable element junctions in marker development and genomic characterization of barley. The Plant Genome, 7: 1-8.

McKie, A.B., Iwamura, T., Leung, H.Y., Hollingsworth, M.A., Lemoine, N.R., 1997. Alu-polymerase chain reaction genomic fingerprinting technique identifies multiple genetic loci associated with pancreatic tumourigenesis. Genes, Chromosomes and Cancer, 18(1): 30-41.

Menconi, G., Battaglia, G., Grossi, R., Pisanti, N., Marangoni, R., 2013. Mobilomics in Saccharomyces cerevisiae strains. BMC Bioinformatics, 14: 102.

Nair, A.S., Teo, C.H., Trude, S., Pat, H.H., 2005. Genome classification of banana cultivars from South India using IRAP markers. Euphytica, 144(3): 285-290.

Nasri, S., Mandoulakani, B.A., Darvishzadeh, R., Bernousi, I., 2013. Retrotransposon insertional polymorphism in Iranian bread wheat cultivars and breeding lines revealed by IRAP and REMAP markers. Biochemical Genetics, 51(11-12): 927-943.

Ovchinnikov, I., Troxel, A.B., Swergold, G.D., 2001. Genomic characterization of recent human LINE-1 insertions: evidence supporting random insertion. Genome Research, 11(12): 2050-2058.

Pandotra, P., Gupta, A.P., Gandhiram, Husian, M.K., Gupta, S., 2013. Genetic and chemo-divergence in eighteen core collection of Zingiber officinale from North-West Himalayas. Scientia Horticulturae, 160(2013): 283-291.

Poczai, P., Varga, I., Laos, M., Cseh, A., Bell, N., Valkonen, J.P.T., Hyvonen, J., 2013. Advances in plant gene-targeted and functional markers: A review. Plant Methods, 19(1): 6.

Ramsay, L., Macaulay, M., Cardle, L., Morgante, M., Degli-Ivanissevich, S., Maestri, E., Powell, W., Waugh, R., 1999. Intimate association of microsatellite repeats with retrotransposons and other dispersed repetitive elements in barley. Plant Journal, 17(4): 415-425.

Roy, A.M., Carroll, M.L., Kass, D.H., Nguyen, S.V., Salem, A.H., Batzer, M.A., Deininger, P.L., 1999. Recently integrated human Alu repeats: finding needles in the haystack. Genetica, 107(1-3): 149161.

Saha, S., Karaca, M., Jenkins, J.N., Zipf, A.E., Reddy, O.U.K., Kantety, R.V., 2003. Simple sequence repeats as useful resources to study transcribed genes of cotton. Euphytica, 130(3): 355-364.

Schrider, D.R., Navarro, F.C.P., Galante, P.A., Parmigiani, R.B., Camargo, A.A., Hahn, M.W., De 
Souza, S.J., 2013. Gene copy-number polymorphism caused by retrotransposition in humans. Plos Genetics, 9(1): e1003242.

Schulman, A.H., Kalendar, R., 2005. A movable feast: Diverse retrotransposons and their contribution to barley genome dynamics. Cytogenetics and Genome Research, 110(1-4): 598-605.

Seibt, K.M., Wenke, T., Wollrab, C., Junghans, H., Muders, K., Dehmer, K.J., Diekmann, K., Schmidt, T., 2012. Development and application of SINEbased markers for genotyping of potato varieties. Theoretical and Applied Genetics, 125(1): 185-196.

Sheen, F.M., Sherry, S.T., Risch, G.M., Robichaux, M., Nasidze, I., Stoneking, M., Batzer, M.A., Swergold, G.D., 2000. Reading between the LINEs: human genomic variation induced by LINE-1 retrotransposition. Genome Research, 10(10): 14961508.

Soorni, A., Nazeri, V., Fattahi, R., Khadivi-Khub, A., 2013. DNA fingerprinting of Leonurus cardiaca L. germplasm in Iran using amplified fragment length polymorphism and interretrotransposon amplified polymorphism. Biochemical Systematics and Ecology, 50: 438-447.

Sveinbjörnsson, J.I., Halldórsson, B.V., 2012. PAIR: polymorphic Alu insertion recognition. $B M C$ Bioinformatics, 13(6): S7.

Teo, C.H., Tan, S.H., Ho, C.L., Faridah, Q.Z., Othman, Y.R., Heslop-Harrison, J.S., Kalendar, R., Schulman, A.H., 2005. Genome constitution and classification using retrotransposon-based markers in the orphan crop banana. Journal of Plant Biology, 48(1): 96-105.

Van Den Broeck, D., Maes, T., Sauer, M., Zethof, J., De Keukeleire, P., D'hauw, M., Van Montagu, M., Gerats, T., 1998. Transposon display identifies individual transposable elements in high copy number lines. The Plant Journal, 13(1): 121-129.

Vicient, C.M., Jaaskelainen, M., Kalendar, R., Schulman, A.H., 2001. Active retrotransposons are a common feature of grass genomes. Plant Physiology, 125(3): 1283-1292.

Vicient, C.M., Suoniemi, A., Anamthawat-Johnsson, K., Tanskanen, J., Beharav, A., Nevo, E., Schulman, A.H., 1999. Retrotransposon BARE-1 and its role in genome evolution in the genus Hordeum. Plant Cell, 11(9): 1769-1784.

Vos, P., Hogers, R., Bleeker, M., Reijans, M., Van De
Lee, T., Hornes, M., Frijters, A., Pot, J., Peleman, J., Kuiper, M., Zabeau, M., 1993. AFLP: A new technique for DNA fingerprinting. Nucleic Acids Research, 23(21): 4407-4414.

Waugh, R., McLean, K., Flavell, A.J., Pearce, S.R., Kumar, A., Thomas, B.B., Powell, W., 1997. Genetic distribution of Bare-1-like retrotransposable elements in the barley genome revealed by sequence-specific amplification polymorphisms (SSAP). Molecular and General Genetics, 253(6): 687-694.

Wicker, T., Sabot, F.,Hua-Van, A., Bennetzen, J.L., Capy, P., Chalhoub, B., Flavell, A., Leroy, P., Morqante, M., Panaud, O., Paux, E., SanMiguel, P., Schulman, A.H., 2007. A unifed classifcation system for eukaryotic transposable elements. Nature Reviews Genetics, 8(12): 973-982.

Witherspoon, D., Xing, J., Zhang, Y., Watkins, W.S., Batzer, M.A., Jorde, L.B., 2010. Mobile element scanning (ME-Scan) by targeted high-throughput sequencing. BMC Genomics, 11: 410.

Witte, C.P., Le, Q.H., Bureau, T., Kumar, A., 2001. Terminal-repeat retrotransposons in miniature (TRIM) are involved in restructuring plant genomes. Proceedings of the National Academy of Sciences USA, 98(24): 13778-13783.

Wong, K., Adams, D.J., Keane, T.M., 2013. Go retro and get a GRIP. Genome Biology, 14(3): 1-3.

Wong, K., Keane, T.M., Stalker, J., Adams, D.J., 2010. Enhanced structural variant and breakpoint detection using SVMerge by integration of multiple detection methods and local assembly. Genome Biology, 11(12): R128

Xing, J., Witherspoon, D.J., Jorde, L.B., 2013. Mobile element biology: new possibilities with highthroughput sequencing. Trends in Genetics, 29(5): 280-289.

You, F.M, Wanjugi, H., Huo, N., Lazo, G.R., Luo, M.C., Anderson, O.D., Dvorak, J., Gu, Y.Q., 2010. RJPrimers: unique transposable element insertion junction discovery and PCR primer design for marker development. Nucleic Acids Research, 38(2): 313-320.

Zietkiewicz, E., Rafalski, A., Labuda, D., 1989. Genome fingerprinting by simple sequence repeat (SSR)anchored polymerase chain reaction amplification. Genomics, 20(2): 176-183. 